NASA Technical Memorandum 8887.4, .

\title{
Effect of Hard Particle Impacts on the Atomic Oxygen Survivability of Reflector Surfaces With Transparent Protective Overcoats
}

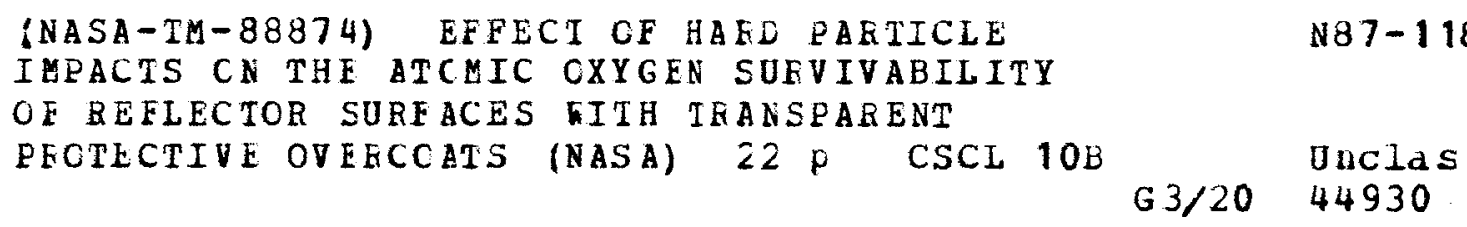

Juclas

44930

N87-11838

Daniel A. Gulino

Lewis Research Center

Cleveland, Ohio

Prepared for the

25th Aerospace Sciences Meeting sponsored by the American Institute of Aeronautics and Astronautics Reno, Nevada, January 12-15, 1987 
Trade names or manufacturers' names are used in this report for identification only. This usage does not constitute an official endorsement, either expressed or implied, by the National Aeronautics and Space Administration. 
EFFECT OF HARD PARTICLE IMPACTS ON THE ATOMIC OXYGEN SURVIVABILITY OF

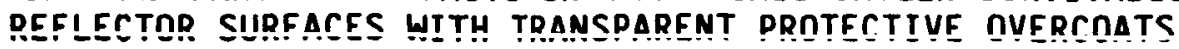

Daniel A. Gulino

National Aeronautics and Space Administration

Lewis Research Center

Cleveland, Ohio 44135

\section{ABSTRACT}

Silver mirror samples with protective coatings were subjected to a stream of $27 \mu \mathrm{m}$ alumina particles to induce pinhole defects. The protective coating consisted of a layer of aluminum dioxide over silver followed by a layer of silicon dioxide over the alumina. Samples were prepared on both graphite-epoxy composite and fused quartz substrates. After exposure to the hard particle stream, the samples were exposed to an oxygen plasma environment in a laboratory plasma asher. The effects of both the hard particles and the oxygen plasma were documented by both reflectance measurements and scanning electron microscopy. The results indicated that oxidative damage to the silver reflecting layer continues beyond that of the erosively exposed silver. Oxidative undercutting of the stiver layer and graphite-epoxy substrate continues in undamaged areas through adjacent, particle damaged defect sites. This may have implications for the use of such mirrors in a Space Station solar dynamic power system.

\section{INTRODUCTION}

Electrical power on the Space Station is currently envisioned to be generated by a combination of both photovoltaic and solar dynamic power systems. Solar dynamic systems generate electricity by reflecting and focusing the sun's energy onto the receiver of a heat engine. An important consideration in the use of a solar dynamic system in space is the survivability of the reflecting surface in the low earth orbit (LEO) environment through which the Space Station will fly. 
The major constituent of the LEO environment is neutral atomic oxygen.' This specte is highly corrosive and is known to attack a number of materials. ${ }^{2-4}$ If silver is used in the mirror as the reflecting medium, then a transparent, protective coating must be applied to the surface to prevent oxidation of the silver by atomic oxygen. Other hazards presented by the LEO environment include micrometeoroids and orbiting space debris. If such particles should strike the surface of the mirror and pierce the protective coating, then oxidative damage to both the underlying silver layer and the substrate is possible. It was the intent of the work to be described here to investigate the effect of particle impact damage on the continued atomic oxygen survivability of silver reflectors with transparent protective overcoats.

\section{APPARATUS AND PROCEDURE}

Mirror samples were prepared by argon ion beam sputtering from a silver target onto graphite-epoxy composite and fused quartz substrates in an apparatus described elsewhere. ${ }^{5}$ The graphite-epoxy had been first polished to a smooth finish with diamond paste. The silver layer was approximately $2000 \mathrm{~A}$. in thickness. The protective coating consisted of a layer of $\mathrm{Al}_{2} \mathrm{O}_{3}$ (approx. 700 A) over the silver and then a layer of $\mathrm{SiO}_{2}$ (approx. $2200 \mathrm{~A}$ ) over the $\mathrm{Al}_{2} \mathrm{O}_{3}$. This particular coating combination was chosen because it is typical of the protective coating systems under consideration for use on solar dynamic concentrator mirrors.

The atomic oxygen environment was simulated by use of a Structure Probe, Inc. Plasma Prep II laboratory plasma asher facility operated with air. This device creates the plasma by exciting a carrier gas (in this case ambient air) with $100 \mathrm{~W}$ of continuous wave RF power at $13.56 \mathrm{MHz}$. The operating pressure is about $50 \mu \mathrm{m}$. While it is difficult to form a direct correlation between 
exposure time in the asher and lifetime in LEO, use of the asher facility does allow gross determination of the likelthood of survivability of a particular material in LEO.

Impact damage and pinhole defects were imparted to the sample surfaces with an Airbrasive high-speed abrasive particle unit using 27 um diameter alumina particles. This unit accelerates the particles to a velocity of about $340 \mathrm{~m} / \mathrm{sec}$ (about $1100 \mathrm{ft} / \mathrm{sec}$ ) at a flux of about $6 \times 10^{12} \mathrm{~cm}^{-2} \cdot \mathrm{sec}^{-1}$.

Samples prepared on graphite-epoxy substrates were characterized by both reflectance measurements and scanning electron microscopy (SEM). Integrated solar reflectances were obtained by measuring the reflectance versus wavelength over the range $200-2500 \mathrm{~nm}$ and then convoluting this spectrum into the air mass zero solar spectrum ${ }^{6}$ over the same wavelength range. 7 In doing so, only about 3 percent of the solar constant is neglected. Such measurements were made for each graphite-epoxy sample as a function of both length of time of exposure to the particle flux and length of time of exposure to the oxygen plasma. Both total and specular reflectances were obtained, the latter of which were measured at an $8^{\circ}$ angle of incidence with an acceptance aperture solid angle of $0.096 \mathrm{sr}$. Samples prepared on fused quartz substrates were characterized only by SEM.

For the graphite-epoxy substrate samples, the procedure was to erode each sample for a different length of time, thereby causing the specular reflectance to fall by a different amount for each sample prior to exposure to the oxygen plasma. Samples were exposed to the particle flux for times ranging in length from 0 to $96 \mathrm{sec}$. This caused the specular reflectance to fall from 0 percent to about 50 percent of the initial, noneroded reflectance. Additional reflectance measurements were then obtained on each 
sample after subsequent oxygen plasma exposure. For the fused quartz substrate samples, each was exposed to the particle flux for the same length of time $(16 \mathrm{sec})$ and then exposed to the oxygen plasma.

\section{RESULTS}

In Figs. 1 and 2 are plotted, respectively, the specular and total reflectance ratios of several of the graphite-epoxy substrate samples as a function of oxygen plasma exposure duration. The reflectance ratios were obtained by dividing the reflectance at a given time by the initial, non-eroded, non-ashed reflectance. The data points at zero hours thus indicate the effect on the reflectance of only the erosive particle stream as a function of duration of exposure to the particle stream. In these plots, three rather broadly defined regions can be observed. During the first roughly $30 \mathrm{hr}$ of exposure, the reflectances fell rather markedly from their initial values, with the degree of fall directly proportional to the length of time of exposure to the particle flux. For the next $60 \mathrm{hr}$, the reflectances remained roughiy constant. After this, they began to decrease once again, and with a rate of decrease that increased with time. These effects were somewhat more pronounced on the specular reflectance plots.

SEM micrographs were obtained after a variety of different treatments and exposure times. Figure 3 is a micrograph of a non-eroded, non-ashed sample on a graphite-epoxy substrate. (The white, irregularly shaped object in the lower left is a dust particle which aided in focusing.) The only feature visible is the ridged structure of the graphite-epoxy substrate. Figure 4 is a micrograph of a sample similar to that in Fig. 3, except that this sample had been exposed to the particle stream. A number of defect sites are evident.

Figures 5 to 9 show the effect of exposure of the particle-eroded, graphite-epoxy substrate samples to the plasma for different lengths of time. 
Figure 5 is a micrograph of a sample that had been exposed in the asher for $50 \mathrm{hr}$. While the region photographed is a different from that of Fig. 4 , their appearance is the same: a variety of differently sized and shaped defect sites. Figure 6 is a micrograph of a sample exposed in the asher for $90 \mathrm{hr}$." The heart-shaped, darkened "rim". surrounding the defect site in the lower left of this photo is a result of oxidation of the silver and/or the substrate surrounding that defect site. The width of the rim is very roughly the diameter of the pinhole defect. Figure 7 is an enlarged view of another defect site on the same sample as Fig. 6. 0xidative undercutting (the darkened rim) is clearly evident. Figure 8 is a micrograph of a sample exposed in the asher for $240 \mathrm{hr}$. In this figure it is evident that oxidative undercutting has occurred to a large degree. The widths of the darkened rims are now nearly ten times the diameter of the defect site.

These photos clearly show that while oxidative undercutting is a process that does not begin immediately, once it does start, its rate accelerates with increasing asher exposure time. This finding explains the shape of the reflectance versus exposure time curves shown in Figs. 1 and 2, particularly the later, rapid fall-off in reflectance. As a final observation in this series, Fig. 9 is a micrograph of the lower right portion of Fig. 8 , taken at a tilt angle of $60^{\circ}$. This figure shows that wherever the undercutting occurred, the surface of the sample had collapsed. This is an indication that oxidation of the substrate had occurred.

The series of SEM micrographs discussed above (Figs. 3 to 9 ) indicates that the reflectance data (figs. 1 to 2) may be explained by the following mechanism: the initial, rapid drop in reflectance was caused by oxidation of those parts of the silver layer directly exposed as a result of the particle-induced damage. After some time (about $30 \mathrm{hr}$ in this case), this 
silver became completely oxidized. The reflectance then remained relatively constant for a perfod of time, during which oxidative undercutting had begun to occur but had not reached the point where the. reflectance was affected. Finally, the reflectance began to fall once again as a result of undercutting of the sllver layer and the substrate in undamaged areas by oxygen plasma attack through adjacent, damaged areas.

Figures 10 to 17 show the effects of exposure of the fused quartz substrate samples to the plasma environment for different lengths of time. For comparison purposes, Fig. 10 (11ke Fig. 3) shows a non-eroded, non-ashed sample. Figure 11 is a micrograph of a sample similar to that in Fig. 10 , except that it has been exposed to the particle stream. As before, a number of defect sites resulting from the particle impacts is evident. Figure 12 is a micrograph of a pitted surface after $50 \mathrm{hr}$ of exposure. While no undercutting (transverse oxidation of the silver, in this case) is readily observed, oxidation of the freshly exposed silver layer is evident as the puffed material protruding from the defect sites. This is more apparent in Fig. 13, which is the same surface as shown in fig. 12, but at a higher magnification and at a sharp tilt $\left(60^{\circ}\right)$.

Figure 14 is a micrograph of an eroded surface after $90 \mathrm{hr}$ of exposure. As before, oxidized silver protruding through the defect sites is clearly evident. Transverse oxidation of the silver after $90 . \mathrm{hr}$ of exposure is more clearly seen in Fig. 15, which is an enlargement of Fig. 14. As in the previous samples, the oxidative damage appears as a discolored rim surrounding the defect site. In Fig. 15, the rim appears brighter in color.

Figure 16 is micrograph showing a pitted surface after $240 \mathrm{hr}$ of asher exposure. As in Fig. 15, a rim lighter in color and surrounding each defect site is evident. Unlike the graphite-epoxy substrate samples, the width of the rim did not appear to increase significantly between the $90 \mathrm{hr}$ and $240 \mathrm{hr}$ 
samples. However, a comparison of Fig. 13 with Fig. 17 (the latter of which is an enlargement of the same surface seen in Fig. 16 , but at a $60^{\circ}$ tilt; shows that the outgrowths of silver oxide had continued unabated. DISCUSSION

It is apparent from the above results that a protective coating over substrate/silver reflector systems such as these cannot protect indefinitely against oxygen plasma-induced degradation when pinhole defects are present. The degradation observed here manifested itself in ways which were dependent upon the kind of substrate material used. The samples prepared on graphite-epoxy composite, which is an oxidizable substrate, showed evidence that the substrate itself was also oxidized through the pinhole defects. This was observed in three ways. First, undercutting; once it began, occurred at a rapid rate. Second, where undercutting had occurred, the surface had collapsed (Fig. 9), indicating that the underlying support of the coating.was disappearing. Third, no silver oxide was observed protruding through the defect sites. This is most 1ikely because there was adequate space avallable beneath the protective coating for the expanding oxide in areas where the substrate itseif had been oxidized.

Samples prepared on fused quartz substrates exhibited somewhat different behavior. While transverse oxidation of the silver did occur, it did so at a slower rate. Also, sliver oxide could be seen protruding through defect sites, indicating that there was insufficient space beneath the protective coating for the expanding oxide. This would be expected if the substrate was not oxidizable, as was the case here.

There are several qualifying circumstances with regard to laboratory simulation of the micrometeoroid/atomic oxygen environment which must be kept in mind when interpreting this data. First, the flux of atomic oxygen in the 
laboratory asher is about three orders of magnitude higher than at proposed Space Station altitudes $\left(10^{15}\right.$ versus $\left.10^{12} \mathrm{~cm}^{-2} \mathrm{sec}^{-1}\right)$. On the other hand, the translational energy of the atomic oxygen in the plasma asher is only about $0.2 \mathrm{eV}$, whereas the translational energy of atomic oxygen in LEO is 4-5 eV. The consequence of these flux and energy differences is that the oxidation rate in the asher is very roughiy two orders of magnitude higher than at a $465 \mathrm{~km}$ Space Station orbit. Second, the actual LEO micrometeoroid environment is different than that used here. $7,8,9$ The alumina particles were not accelerated to hypervelocities, and therefore the damage sites observed may be dffferent from what would be observed after actual micrometeoroid impacts, where it has been shown that the impacting particles line the inside of the resulting hemispherical crater. 8

An actual mirror surface in low earth orbit would have to be exposed to space for a very long time in order for a significant number of pinhole defects to occur. It is perhaps more likely that pinhole defects would occur as a result of the manufacture, transport, and/or deployment of the mirror. Then, whatever their source, those defects would have to exist for quite some time before any change in the reflectance and any consequent degradation in the performance of the mirror could be observed. In conclusion, while it is difficult to determine an exact rate, undercutting of a protective coating and transverse oxidation by atomic oxygen can occur once a pinhole defect has been introduced into the coating. On-orbit testing of a mfrror sample would be necessary to determine actual reflectance loss rates from both micrometeoroid/space debris impacts and subsequent atomic oxygen degradation.

\section{REFERENCES}

1. U.S. Standard Atmosphere, 1976, U.S. Government Printing Office, Washington, D.C., 1976, p. 30 . 
2. Banks, B.A., Mirtich, M.J., Rutledge, S.K., and Nahra, H.K., "Protection of Solar Array Blanket from Attach by Low Earth Orbital Atomic Oxygen," Proceedings of the 18th IEEE Photovoltaic Specialists Conference, IEEE, New York, 1985, pp. 381-386.

3. Leger, L.L., "Oxygen Atom Reaction With Shuttle Materlals at orbital Altitudes," AIAA Paper 83-0073, Jan 1983.

4. Whitaker, A.F., "LEO Atomic Oxygen Effects on Spacecraft Materials," AIAA Paper 83-2632-CP, Nov. 1983.

5. Gulino, D.A., "Ion Beam Deposited Zinc Telluride Ftlms," Journal of Vacuum Science and Technology A, Vo1. 4, No. 3, May-June 1986, pp. 509-573.

6. Raushenbach, H.S., Solar Cell Array Design Handbook, Van NostrandReinhold, New York, 1980, p. 411.

7. Mirtich, M.J. and Mark, H., "The Effect of Hypervelocity Projectile Material on the Ultimate Reflectance of Bombarded Polished Metals," NASA TM X-52981, 1971.

8. Bowman, R.L., Mirtich, M.J. and Weigand, A.J., "Changes in Optical Properties of Various Transmitting Materials Due to Simulated Micrometeroid Exposure," NASA TM X-52687, 1969.

9. Mirtich, M.J. and Bowman, R.L., "Effect of Simulated Micrometeoroid Exposure on Performance of N/P Silicon Solar Cells, "AIAA Journal, Vol. 5, No. 7, July 1967, pp. 1364-1366. 


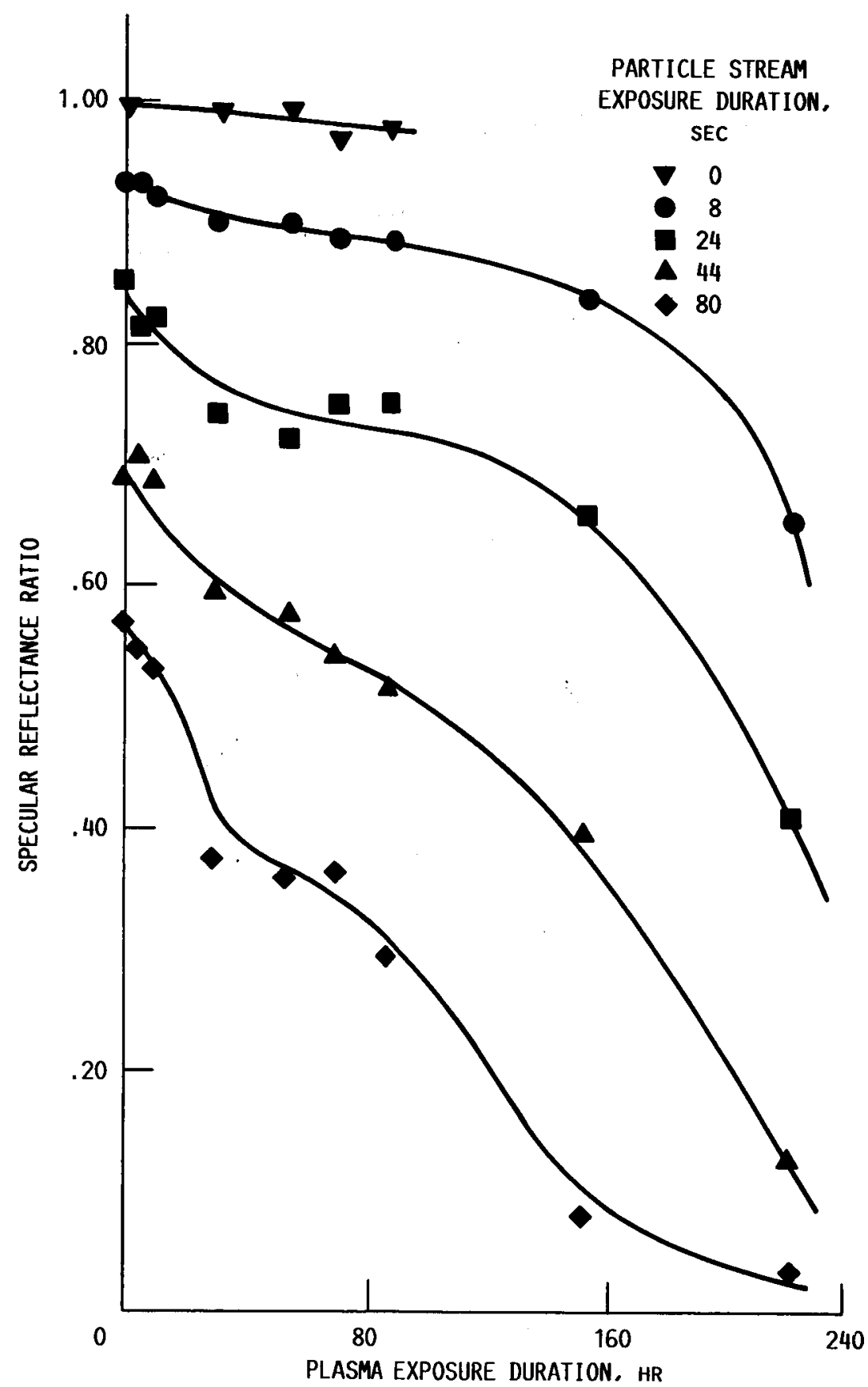

Figure 1.- SPECULAR REFLECTANCE RATIO VERSUS PLASMA EXPOSURE TIME FOR SEVERAL GRAPHITE-EPOXY SUBSTRATE SAMPLES FOR VARIOUS LENGTHS OF TIME OF EXPOSURE TO THE EROSIVE PARTICLE STREAM. THE RATIO IS CALCULATED BY DIVIDING THE REFLECTANCE AT A GIVEN TIME BY THE REFLECTANCE MEASURED PRIOR TO PARTICLE EXPOSURE. 


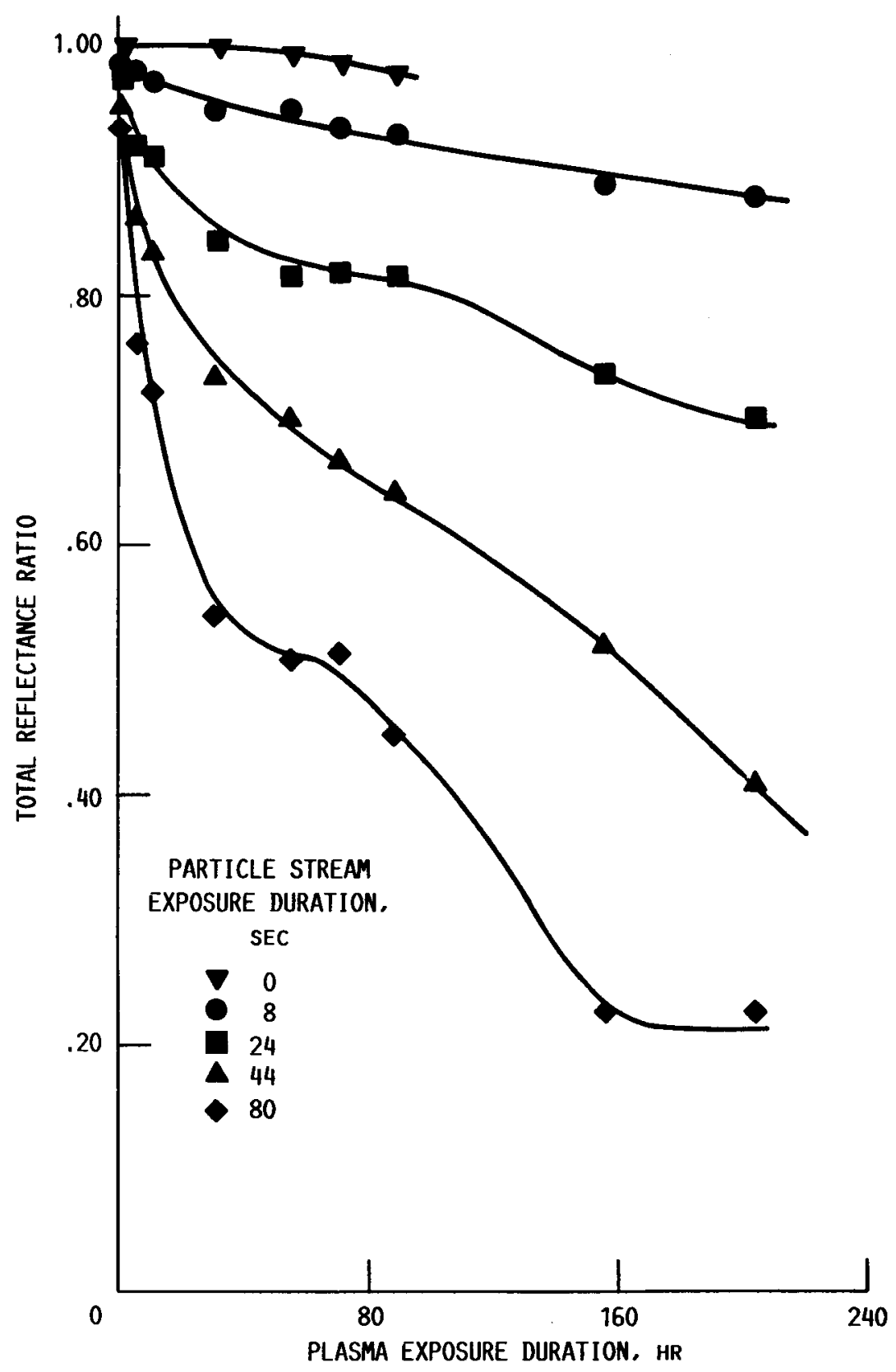

Figure 2.- TOTAL REFLECTANCE RATIO VERSUS PLASMA EXPOSURE TIME FOR SEVERAL GRAPHITE-EPOXY SUBSTRATE SAMPLES FOR VARIOUS LENGTHS OF TIME OF EXPOSURE TO THE EROSIVE PARTICLE STREAM. THE METHOD OF CALCULATION IS IDENTICAL TO THAT OF FIGURE 1. 


\section{ORIGINAL PAGE IS}

OF. POOR FUALIT:

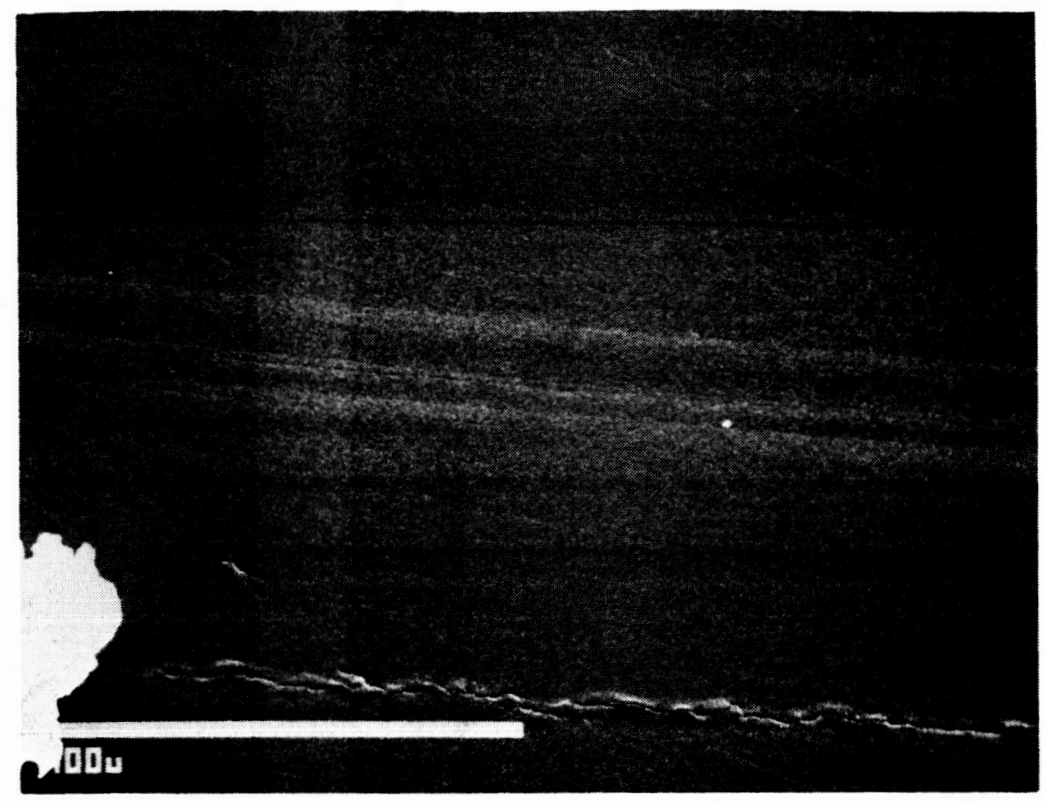

Figure 3. - Micrograph tAKEN AT 500X SHOWIng a NON-EROdED, NONASHED GRAPHITE-EPOXY SUBSTRATE SAMPLE. ONLY THE RIDGED STRUCTURE OF THE SUBSTRATE IS VISIBLE.

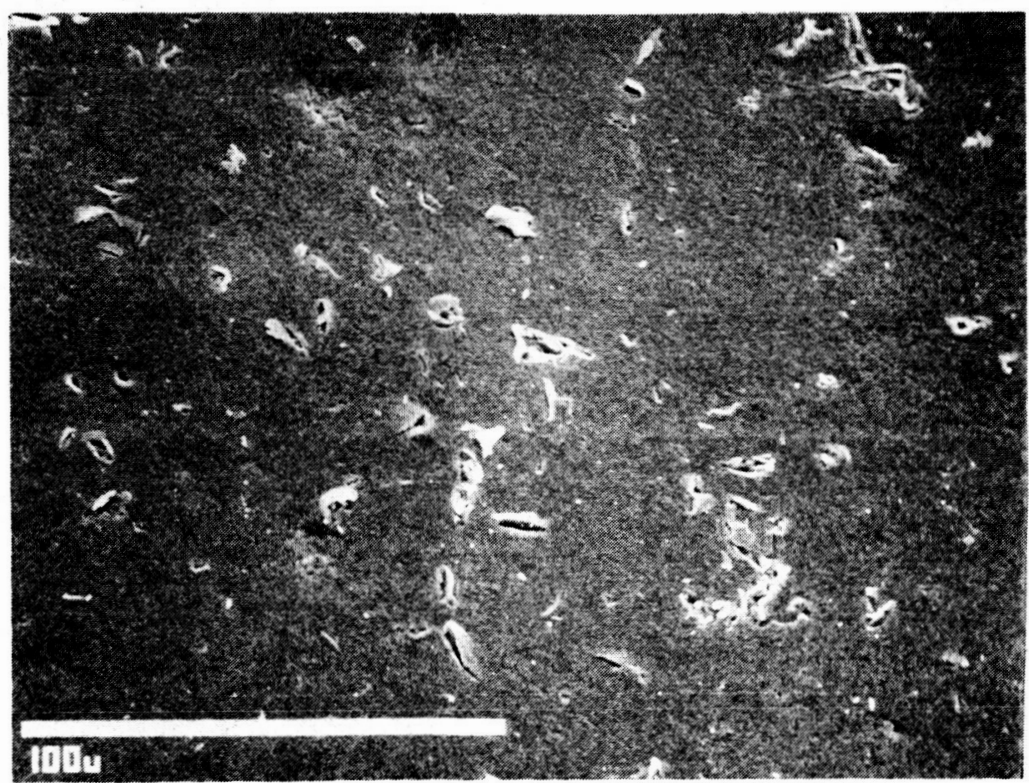

Figure 4. - Micrograph taken at 500X SHOWIng the EFFECT OF THE EROSIVE PARTICLE STREAM ONLY (NO PLASMA EXPOSURE) ON A GRAPHITE-EPOXY SUBSTRATE SAMPLE. A NUMBER OF DEFECT SITES ARE EVIDENT. 


\section{ORIGINAL PATE IS \\ OF. POOR QUALTYY}

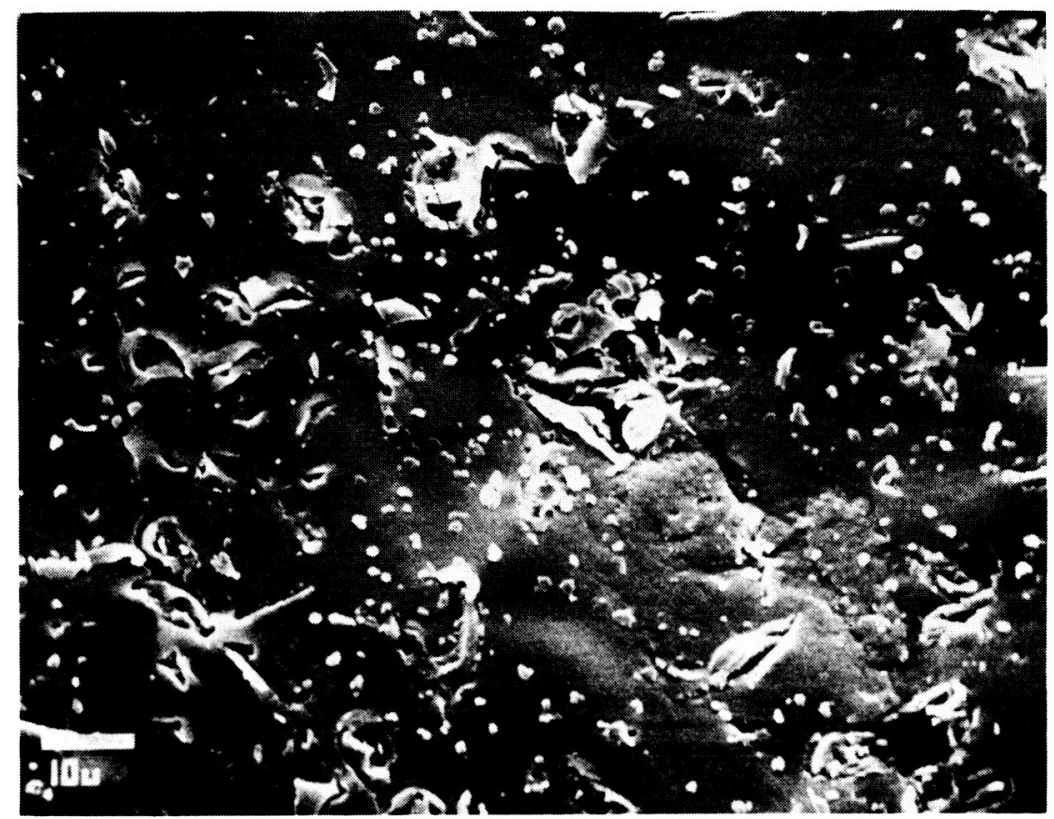

Figure 5. - MicRograph taken at 1000x SHOWIng a PARTICLE ERODED SURFACE AFTER 50 HOURS OF EXPOSURE TO THE OXYGEN PLASMA. THE APPEARANCE IS SIMILIAR TO THAT OF FIGURE 4. NO EVIDENCE OF UNDERCUTTING IS VISIBLE.

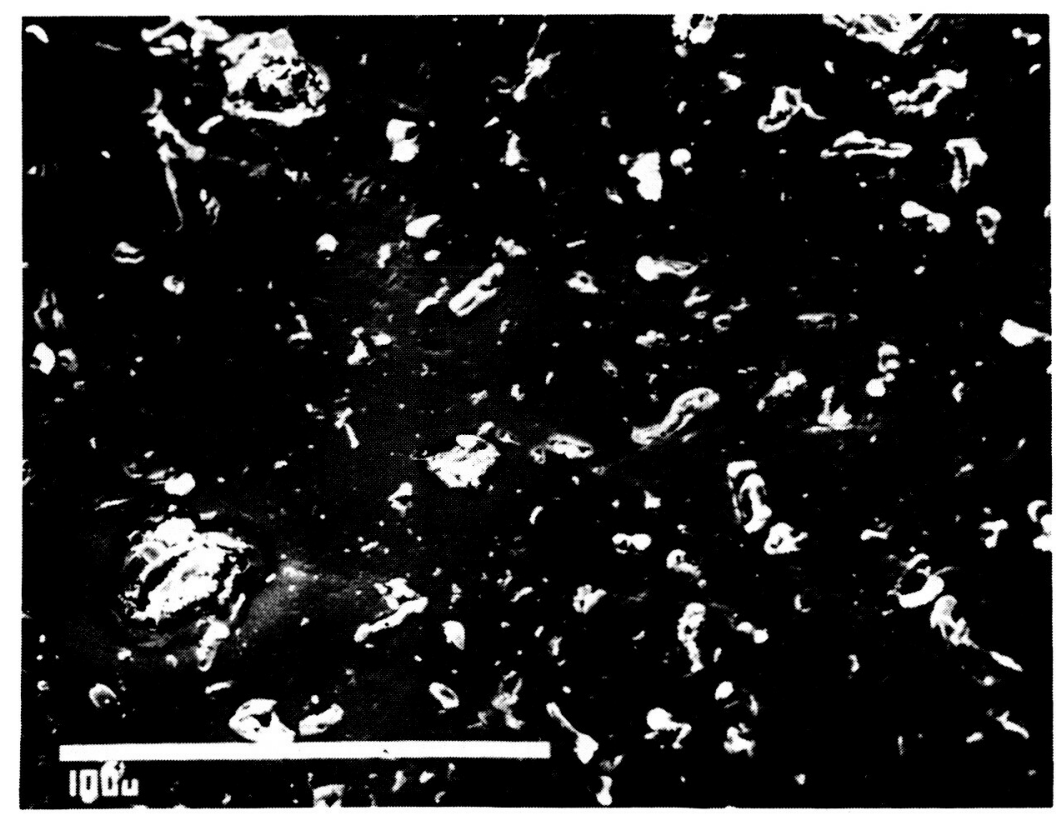

Figure 6. - MiCROgRaPh taken at 500X SHOWING A PARTICLE ERODED SURFACE AFTER 90 HOURS OF EXPOSURE TO THE OXYGEN PLASMA. THE DARKENED "RIM" SURROUNDING THE HEART-SHAPED DEFECT IN THE LOWER LEFT IS OXIDATION OF THE SILVER LAYER AND/OR THE SUBSTRATE BENEATH THE PROTECTIVE COATING. 


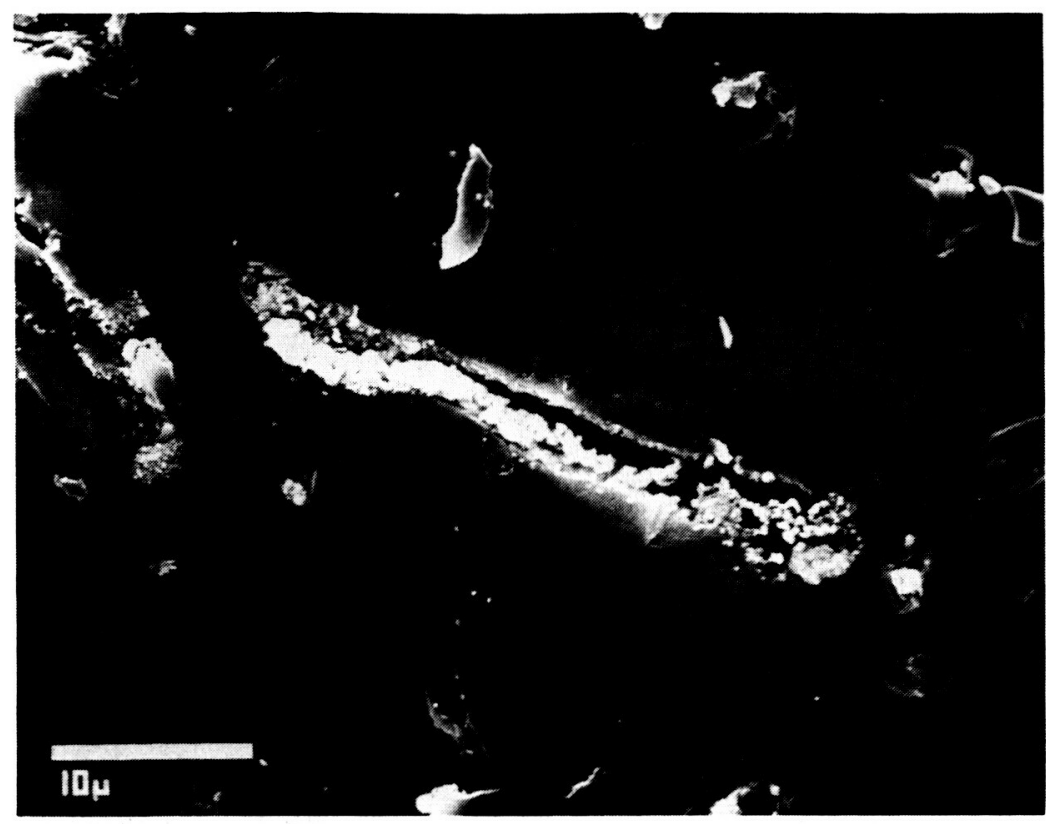

Figure 7. - Micrograph taken at 2000x of a feature on the same SAMPLE AS DEPICTED IN FIGURE 6. OXIDATIVE UNDERCUTTING CAN BE SEEN CLEARLY AS THE DARKENED "RIM" SURROUNDING THE ELONGATED DEFECT.

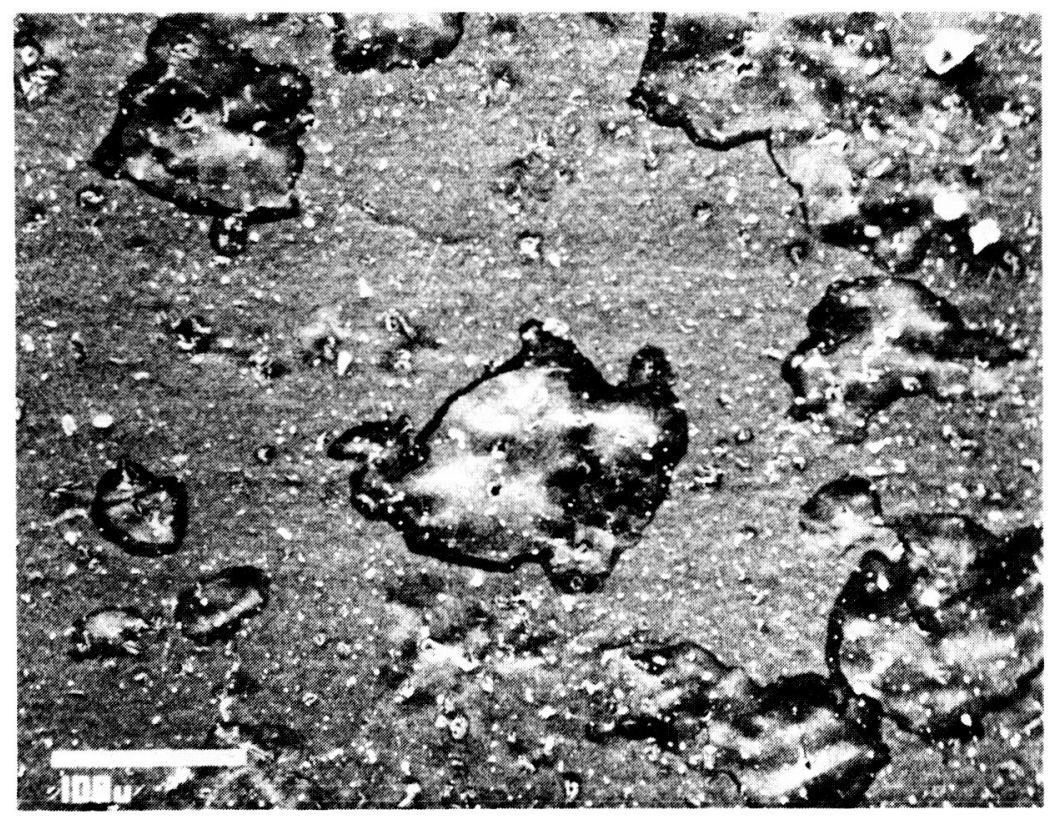

Figure 8. - Micrograph taken at 200x SHOWIng a PARTICLE ERODED SURFACE AFTER 240 HOURS OF EXPOSURE TO THE OXYGEN PLASMA. THE DARKENED AREAS SURROUNDING THE DEFECT SITES HAVE GROWN CONSIDERABLY IN SIZE RELATIVE TO THE SIZE OF THE PINHOLE, INDICATING THAT OXIDATIVE UNDERCUTTING HAS OCCURRED TO A SIGNIFICANT DEGREE. 


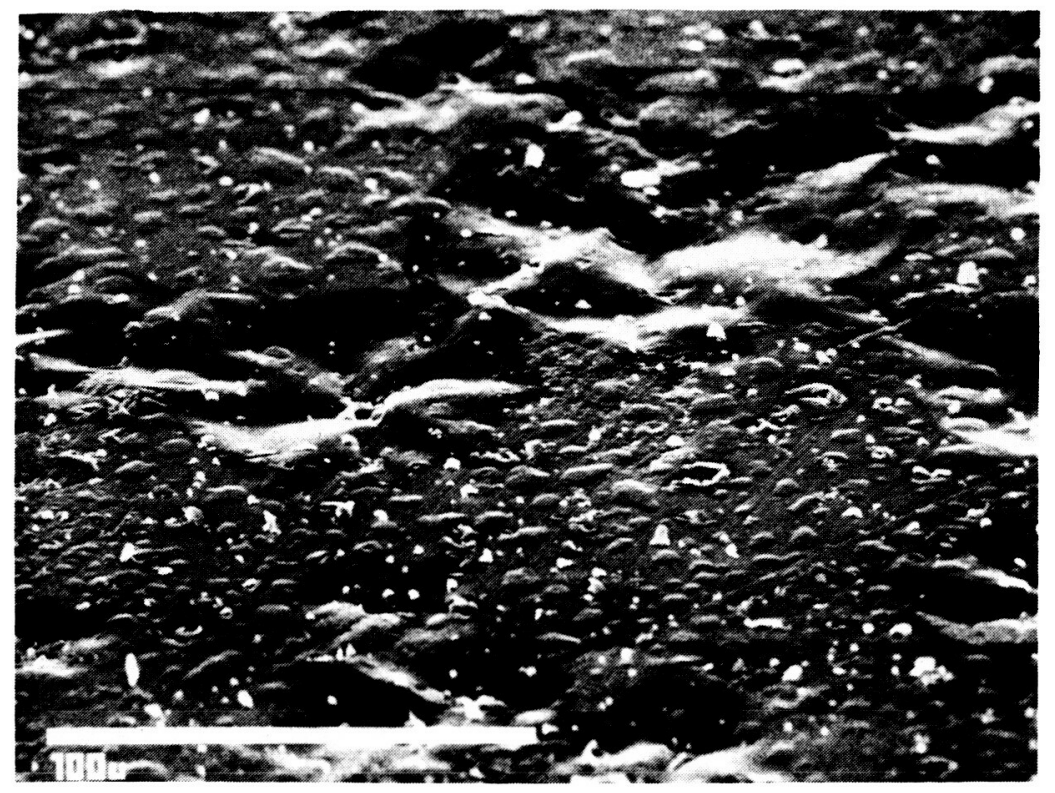

Figure 9. - Micrograph taken at 500x OF THE LOWER RIght PORTION OR FIGURE 8 AT A SHARP ANGLE $\left(60^{\circ}\right)$ SHOWS THAT WHEREVER UNDERCUTTING HAD OCCURRED, THE SURFACE HAD COLLAPSED.

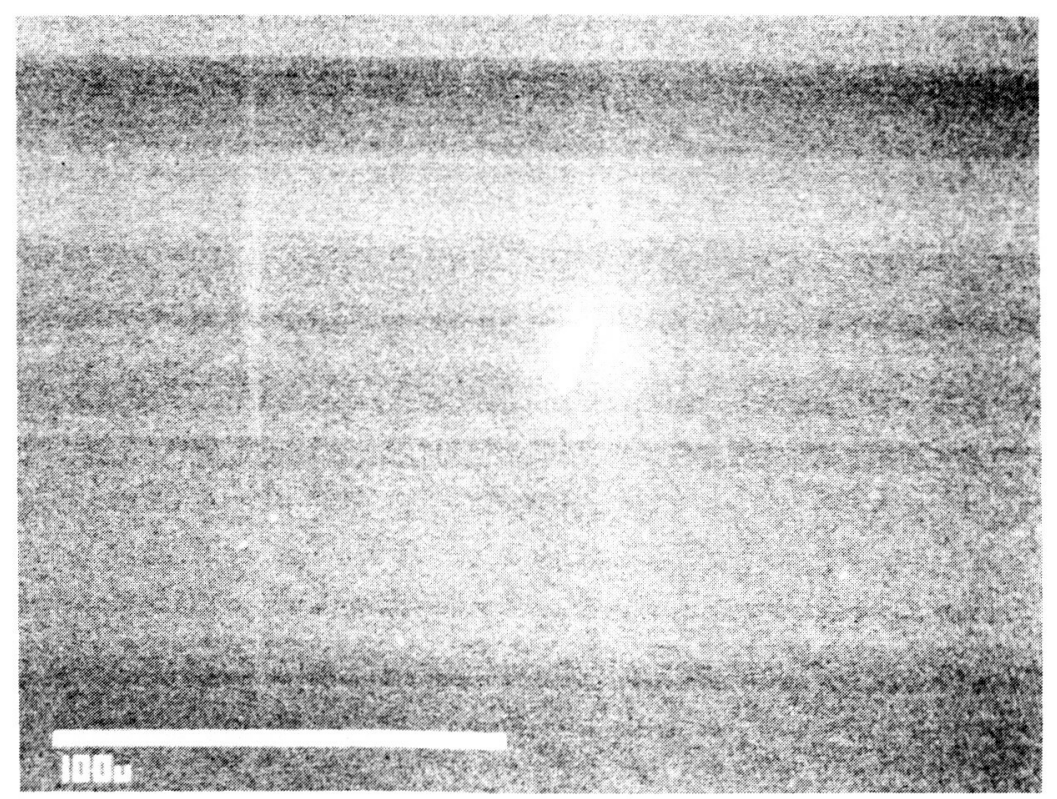

Figure 10. - Micrograph taken at 500X SHOWING A NON-ERODED, NONASHED FUSED QUARTZ SUBSTRATE SAMPLE. 


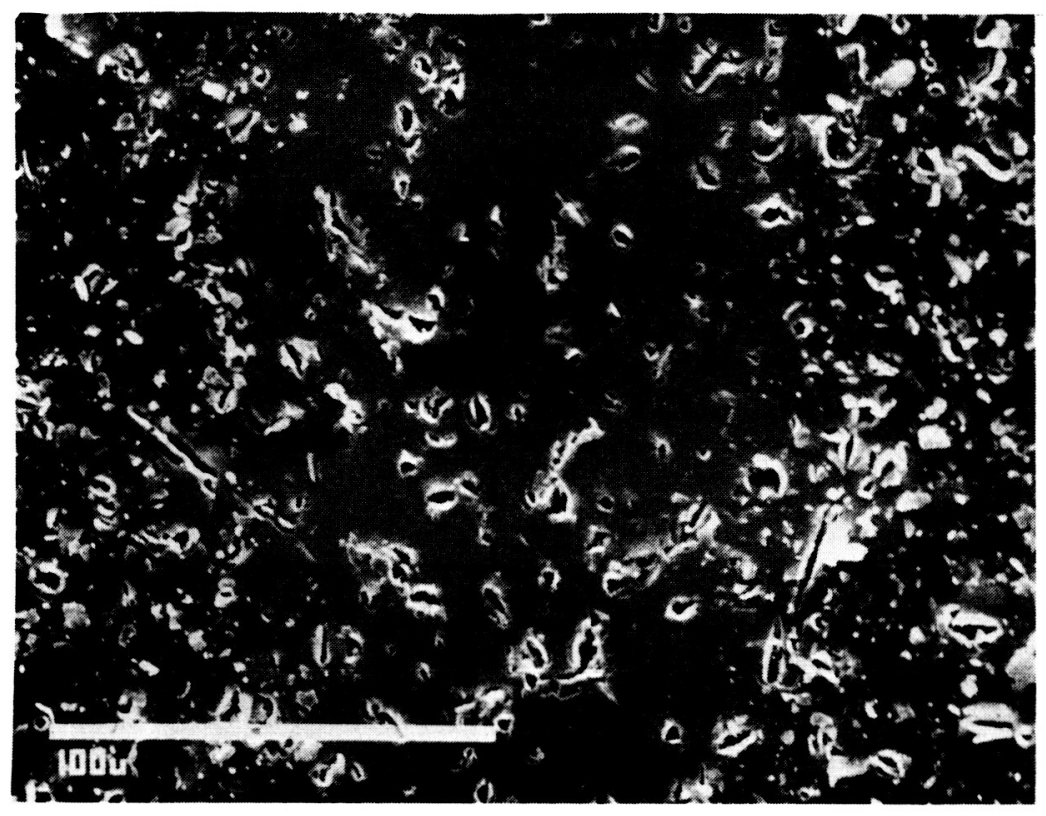

Figure 11. - Micrograph taken at 500x showing the surface of a FUSED QUARTZ SUBSTRATE SAMPLE AFTER EXPOSURE TO THE PARTICLE STREAM BUT PRIOR TO EXPOSURE TO THE OXYGEN PLASMA.

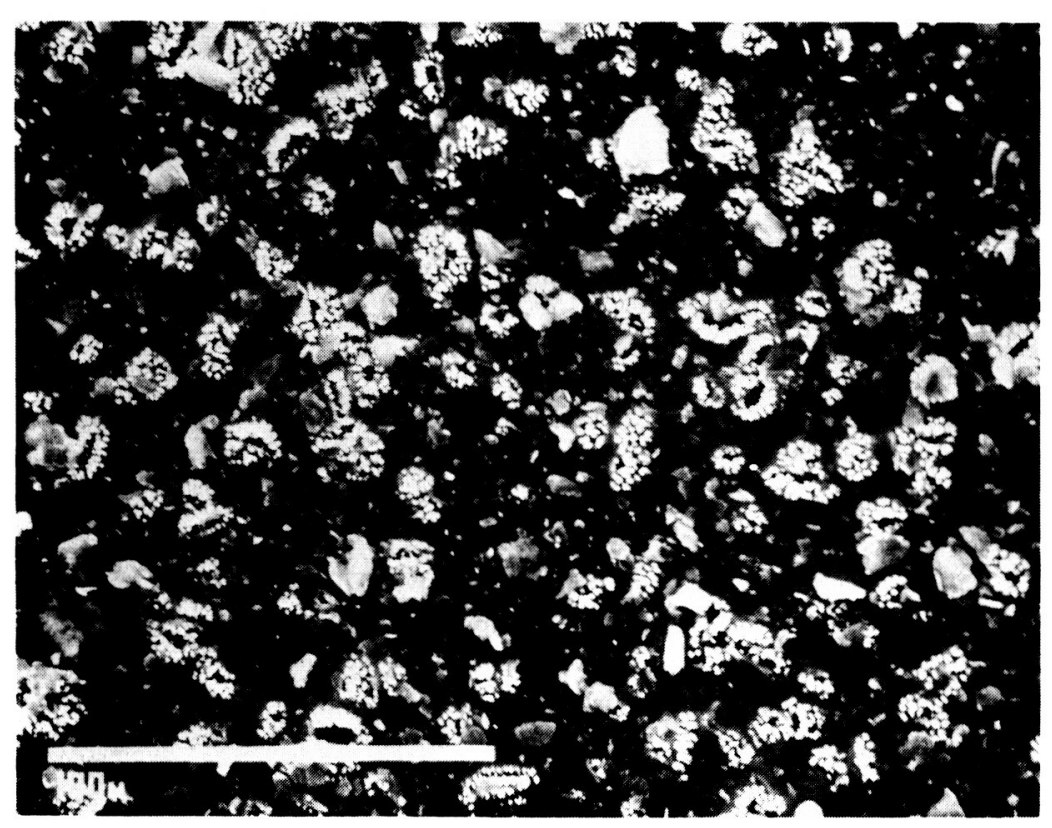

Figure 12. - Micrograph taken at 500x SHOWING THE SURFACE OF A SAMPLE IDENTICAL TO THAT OF FIGURE 11, BUT AFTER 50 HOURS OF EXPOSURE TO THE OXYGEN PLASMA. WHILE NO TRANSVERSE OXIDATION CAN BE SEEN, OXIDATION OF THE SILVER LAYER IS EVIDENT AS THE PUFFY MATERIAL PROTRUDING FROM THE DEFECT SITES. 


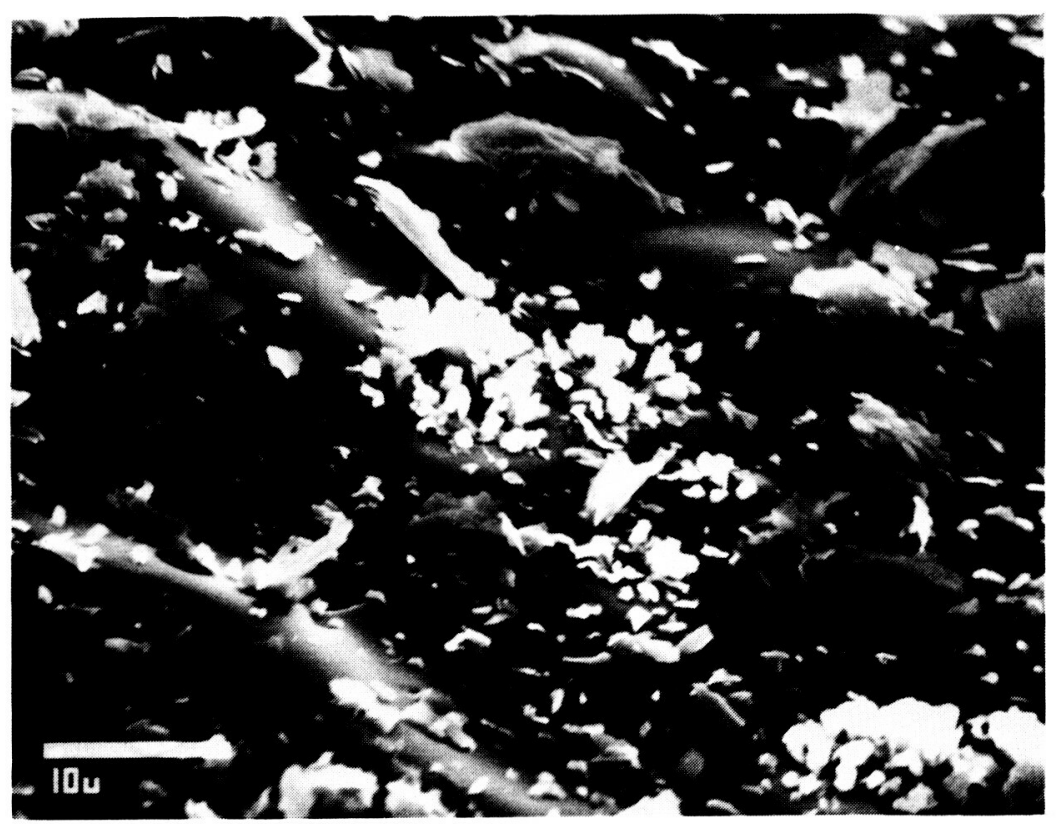

Figure 13. - Micrograph OF the SAME SAMPLE AS THAT OF Figure 12 BUt AT 2000X AND AT A $60^{\circ}$ TILT ANGLE. THE OXIDIZED SILVER, WHICH TAKES THE FORM OF A PUFFY MATERIAL PROTRUDING THROUGH THE DEFECT SITES, IS CLEARLY EVIDENT.

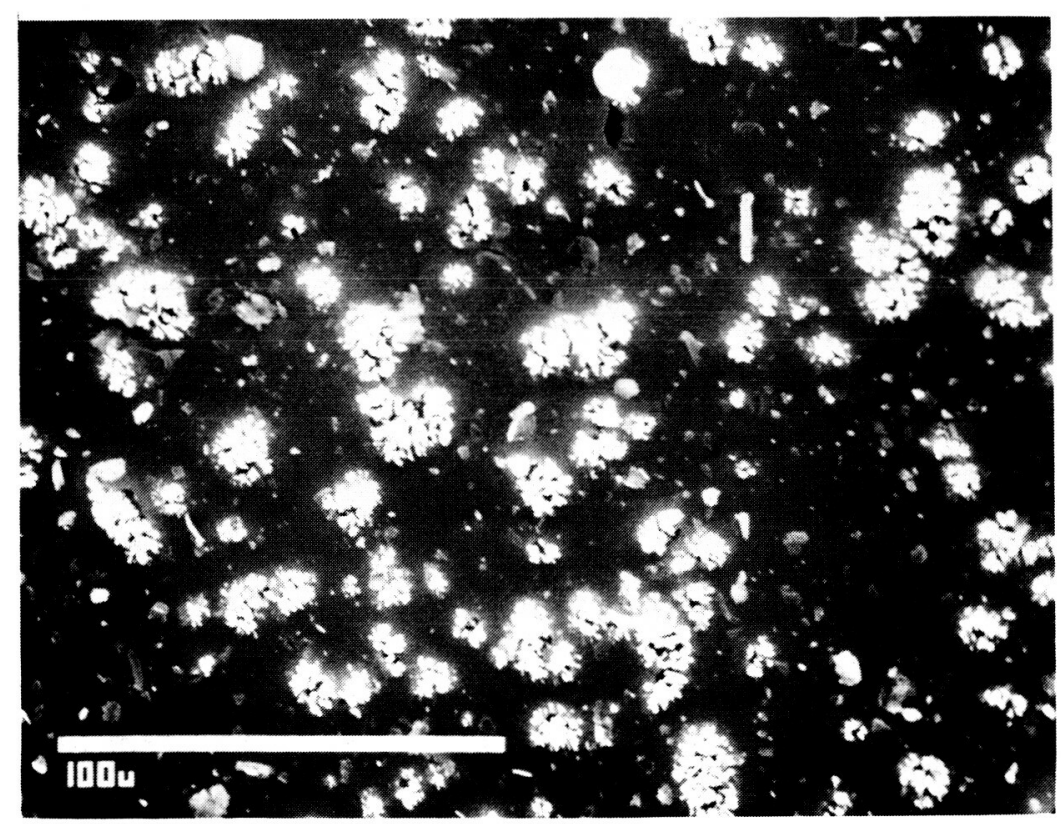

Figure 14. - Micrograph taken at 500X SHOWING THE SURFACE OF A FUSED QUARTZ SUBSTRATE SAMPLE AFTER PARTICLE EROSION AND 90 HOURS OF EXPOSURE TO THE OXYGEN PLASMA. OXIDIZED SILVER IS SEEN PROTRUDING THROUGH THE DEFECT SITE. TRANSVERSE OXIDATION IS VISIBLE AS A BRIGHTER RIM SURROUNDING THE DEFECT SITE. 


\section{ORGILAR PAGE IS OF POOR QUALTY}

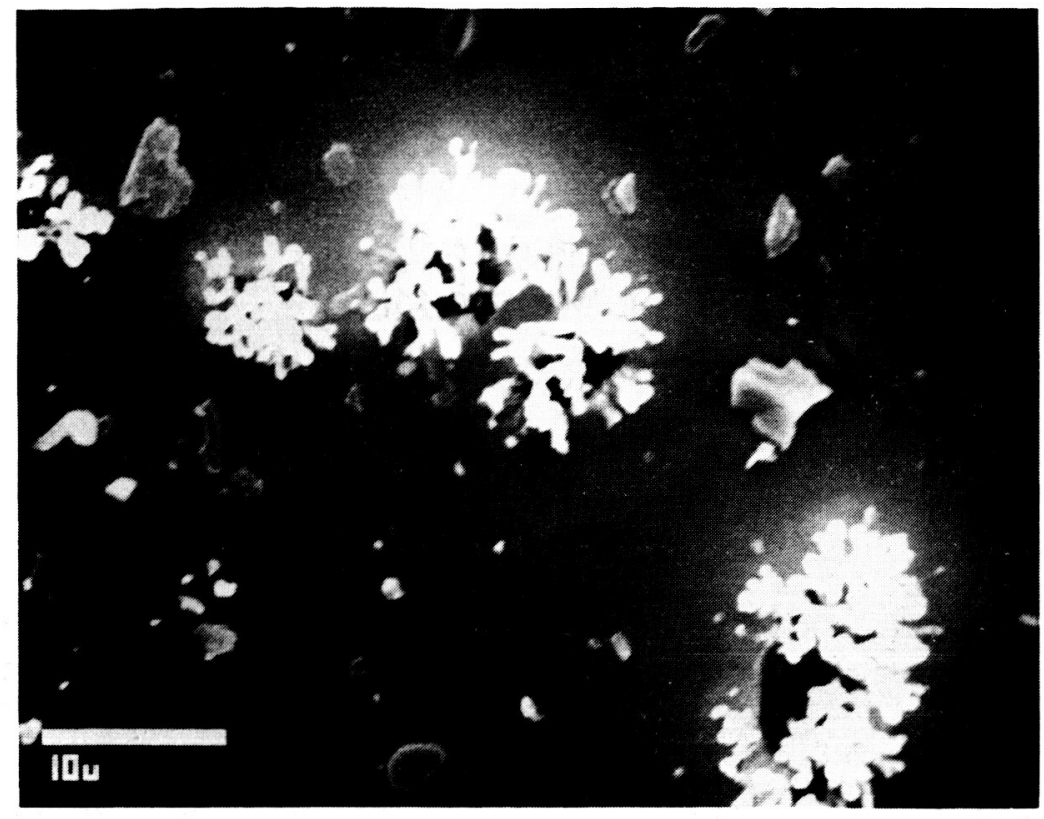

Figure 15. - Micrograph of the same sample as that of figure 14, BUt AT 2000X. TRANSVERSE OXIDATION IS CLEARLY EVIDENT AS A BRIGHTER RIM SURROUNDING THE DEFECT SITE.

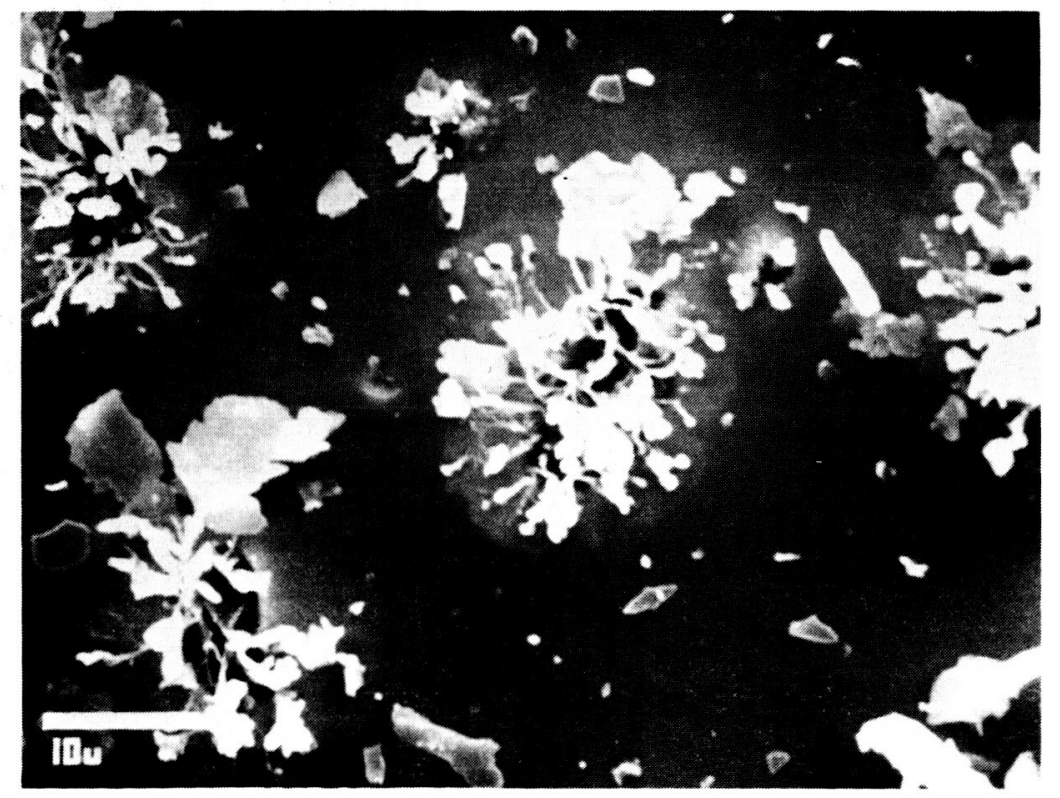

Figure 16. - Micrograph taken at 2000x SHOWing the SURFace of a FUSED QUARTZ SUBSTRATE SAMPLE AFTER PARTICLE EROSION AND 240 HOURS OF OXYGEN PLASMA EXPOSURE. TRANSVERSE OXIDATION IS EVIDENT: HOWEVER, ITS EXTENT DID NOT INCREASE SIGNIFICANTLY OVER THAT OF THE 90 HOUR SAMPLE (FIgS. 14 AND 15). 


\section{ORIGINAL PAGE IS \\ OF POOR QUALTI}

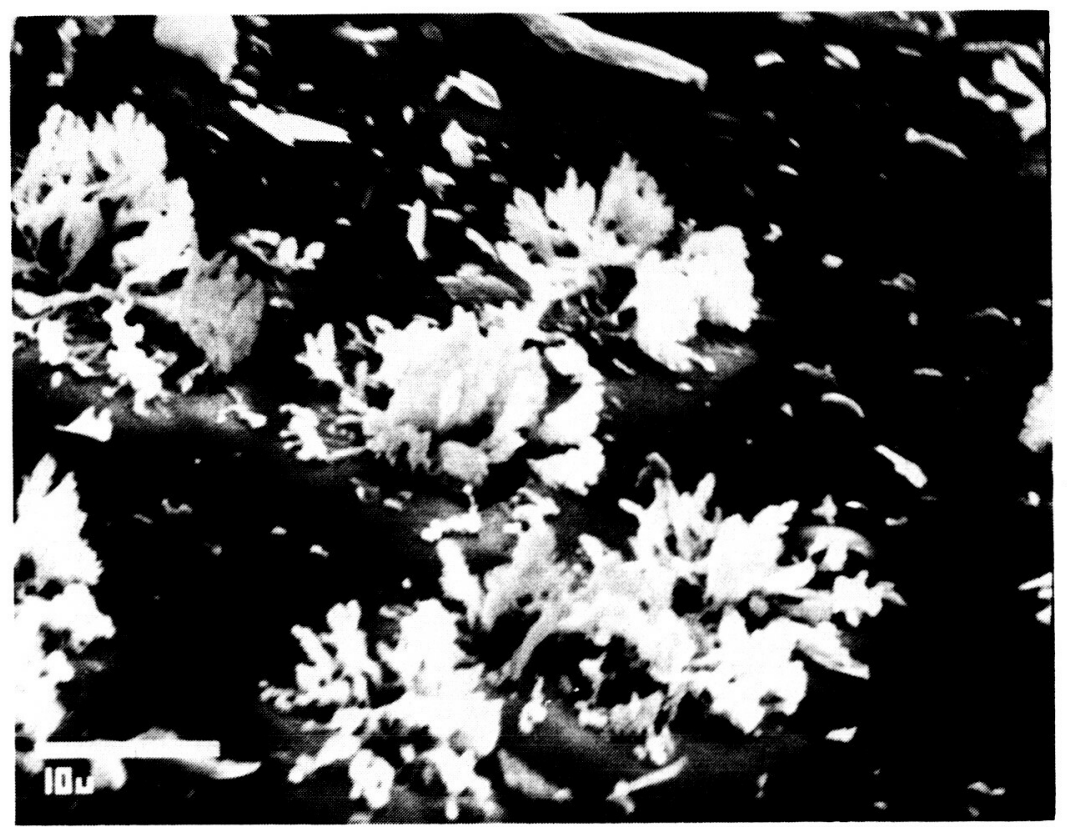

Figure 17. - Micrograph OF the SAME SAMPLE AS that OF FIgURE 16 AT THE SAME MAGNIFICATION AND A $60^{\circ}$ TILT. OUTGROWTH OF OXIDIZED SILVER HAD BEEN CONTINU, NG AS OF 240 HOURS. 


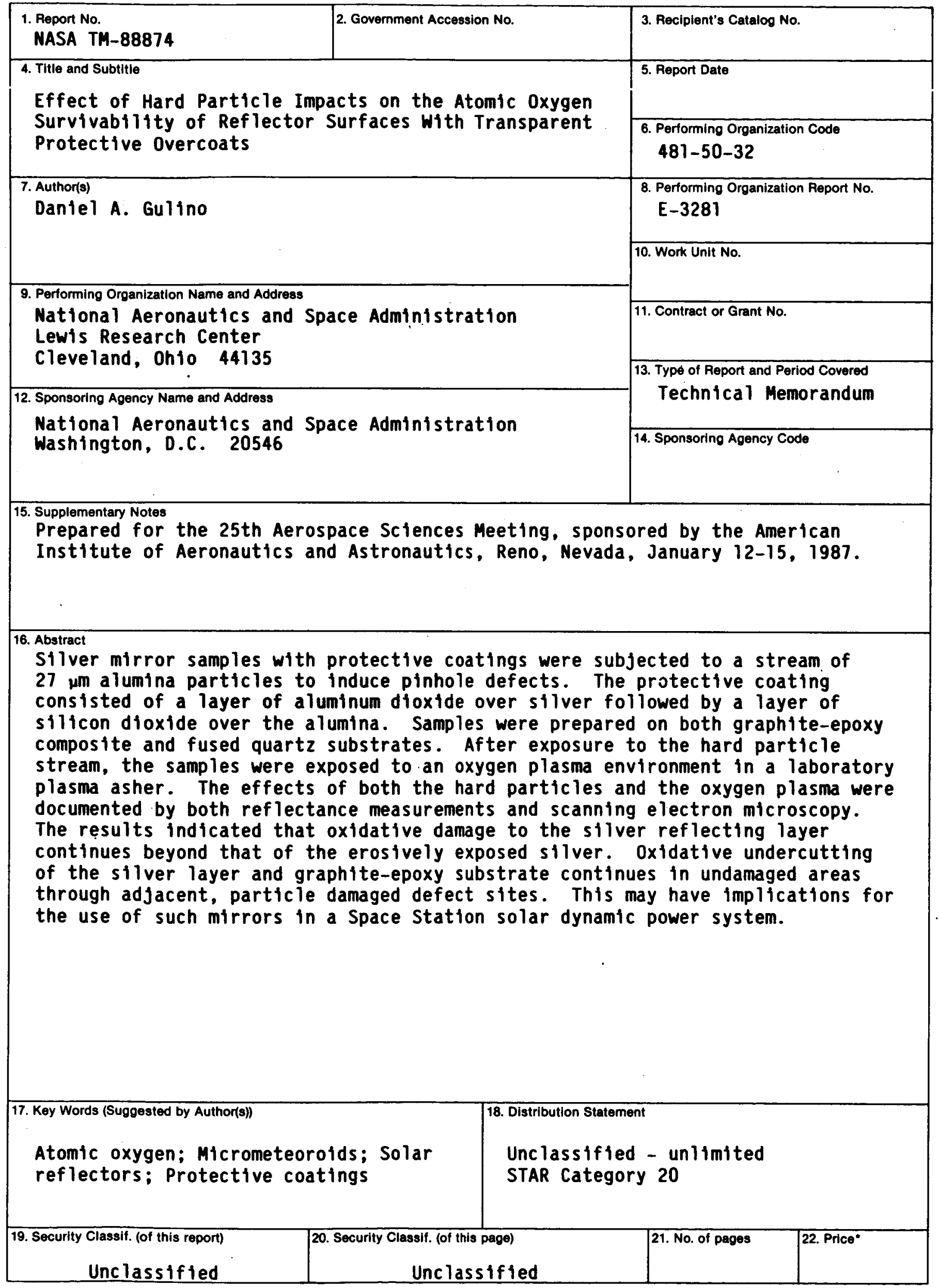

"For sale by the National Technical Information Service, Springfield, Virginia 22161 